\title{
Origins of the Commercial Hospitality Industry: From the fanciful to factual
}

\begin{abstract}
Purpose - Explore some of the different historical roots of commercial hospitality in three distinct epochs with the intention of promoting further empirical research and beginning an informed debate into the origins and evolution of the contemporary hospitality industry.
\end{abstract}

Design/methodology/approach - Report on empirical research based on texts, artefacts and archaeological evidence. Wherever possible all the primary sources were consulted in the original languages; all translations are the author's own unless otherwise stated.

Findings - Contrary to established and often fanciful rhetoric, commercial hospitality has at least 4000 years of history in the area of investigation. The rich and incredibly diverse heritage of the hospitality industry is illustrated and the conclusions emphasise that hospitality research should focus on deepening understanding of the industry through empirical research; learning from the past helps to inform the future.

Research limitations/implications - The particular focus of this article is restricted to reporting to empirical studies of three epochs: Mesopotamia (c. $2000 \mathrm{BC}$ ); Pompeii (79 AD), and Middle Eastern Trade Routes (c. 700 AD onwards). These distinct time periods illustrate the different roots and highlight the need for further research into the evolution of the commercial hospitality industry.

Originality/value - The origins of commercial hospitality is an under-researched area in hospitality management and this paper highlights the rich data that is available through disciplined empirical study.

\section{Introduction}

Exploring the historical roots of commercial hospitality has practical value to the contemporary hospitality industry; O'Connor (2005, p. 267) highlighted: 'only once an understanding of hospitality's origins and its place in human nature is achieved can one expect to discover what hospitality means today, and more importantly what it will mean to those entering the industry in the future'. However the origins of the commercial hospitality industry remain somewhat of an enigma, made more so by the various approaches used to identify them. This paper explores some of the origins of the commercial hospitality industry in Europe and the Middle East in order 
to illustrate not only how complex these industries are, but also how valuable and rewarding disciplined research can be.

\section{Approaches to identifying the origins of commercial hospitality}

When reviewing the history and evolution of commercial hospitality, two basic approaches in the literature can be found. The first is declarative and the second is judgemental.

The declarative statement approach is designed to illustrate common roots or starting points, for example, Rutes and Penner (1985) claimed to trace the development of contemporary commercial hospitality to four basic roots:

1. Commercial hotels can be traced to facilities provided to expedite trade or mail delivery, or to accommodate government and religious travelers.

2. Resorts and entertainment-based facilities are related to Greek and Roman spas.

3. Rental housing and rooming houses eventually led to condos, timeshares and bed and breakfast facilities.

4. Royal courts led to superluxury hotels, castles and condominiums

Similarly, King (1995) argues that commercial hospitality has developed from only two roots: the luxury accommodation of aristocrats, and particularly minimum level accommodation provided for commoners. Other examples include: Lattin (1989) who states that a history of lodging dates back 12,000 years, without offering any evidence as to why; Medlik and Ingram (2000) claim that the hotel industry has 200 years of history, and Bardi (2007) declares that the founders of the hotel industry are Statler, Hilton, and Marriott etc.

The judgemental approach is aimed at implying that commercial hospitality is somehow ignoble compared to other forms of hospitality. This type of questionable rhetoric can be traced to Muhlmann (1932) (succinctly summarised by Wood (1994)) where the commercial context of hospitality is described as a "formal and rational system of (usually monetary) exchange whereby hospitality is provided in particular institutional forms (hotels, restaurants) that are essentially impersonal... for the most part, hospitality is no longer about the personal giving of the host's own food and accommodation but a matter of impersonal financial exchange." This reflection on the hospitality industry within a narrowly and poorly defined commercial context has permeated through hospitality literature. It was developed, for example, by Gillespie and Morrison (2001, p. 115) amongst others, when they argued that "commercial hospitality provision arose from a general process of modernisation, the gradual breakdown of the importance of kinship and social duty of care" and variations on this description are repeated in Morrison (2001). 
These two approaches are further characterised by sweeping statements not backed up with any apparent empirical research evidence. Analysing examples of the history of commercial hospitality, looking for examples of similar practices in contemporary cultures in the world today, whilst being illuminating can have its difficulties. All writing is the product of a particular time and culture, the views expressed in it and the language in which they are expressed reflect a particular cultural conditioning; often making them quite different from contemporary ideas and concerns. Both these approaches also illustrate the potential error of considering any hospitality event out of its proper time, location or context (domestic, civic and commercial) and then subsequently comparing it to any other hospitality event from another time or context. This atemporal and crosscontextualisation is referred to by Finley (1983) as the teleological fallacy. Although the statements made may be given some credibility because they sound convincing and echo characteristics within other hospitality literature; that humanity's organic and spiritual qualities have disappeared and everything is being replaced with commerce. Fortunately, this is at worst simply not true, or at best a myopic and one-sided view of society. This paper presents the results from empirical research of three epochs, illustrative of different historical roots of the industry.

\section{Origins and evolution of the commercial industry}

In order to gain an understanding of the origins of commercial hospitality, three particular epochs are explored using both archaeological and textual evidence. Hospitality in the early legal codes and writings Mesopotamia (c. 2000B.C.) and Greece (c. 500 B.C.) illustrates the origins of the industry within two ancient civilisations. Roman Pompeii (A.D. 79) highlights the importance of historical sites when trying to create a picture of the industry. Finally, a portrait of the caravanserais of Middle Eastern trading routes (c. A.D. 700 onwards) shows that textual and archaeological sources can give an indication of how traditional commercial hospitality supports commerce and trade.

\section{Mesopotamia - Hospitality in Early Legal Codes and Writings}

Although, as yet, no archaeological evidence of commercial hostels and taverns in ancient Mesopotamia has been identified, there is a large diorite stela in the Louvre Museum containing inscriptions commonly known as the Code of Hammurabi. The original purpose of the stela is somewhat enigmatic, however within the inscription, there are laws governing commercial hospitality from at least 1800 B.C. Hostels and inns in Mesopotamia were in the business of supplying drinks, women, and accommodation for strangers. Drinks included datepalm wine and barley beer, and there were strict regulations against diluting them. Driver and Miles (1952) in the 
translation of the stela show that the punishment for watering-down beer was death by drowning, there was also a requirement that tavernkeepers, on pain of death, report all customers who were felons. Other hospitality related laws include women who had retired from the priestly office caught entering an inn, were to be burned alive; according to Richardson (2000) the assumption was that she was going there for sex. The general level of the clientele and surroundings are illustrated by the saying: 'If a man urinates in the tavern in the presence of his wife, he will not prosper... He should sprinkle his urine to the right and the left of the door jambs of the tavern and he will prosper' (Gelb 1956:s.v. astammu).

Commercial hostels were referred to in contemporaneous religious hymnody as for example in the following:

"I enlarged the footpaths, straightened the highways of the land, I made secure travel, built there 'big houses' [hostels of some sort], Planted gardens alongside of them, established resting-places, Settled there friendly folk, (So that) who comes from below, who come from above, Might refresh themselves in its cool, The wayfarer who travels the highway at night, Might find refuge there like in a well-built city" (Pritchard, 1955, p. 585)

The official referred to in the hymn founded fortified settlements to maintain sizeable government hostels along the major roads to service the needs of the travellers, regardless of whether they were official visitors or traders. Jones and Snyder (1961) give a detailed account of large scale hospitality in operation at Lagash in Babylonia (modern day Iraq). It ensured efficient movement of administrators, couriers, and army personnel between the capital and the subject cities; distances which varied from 100 to 400 miles away. The travel orders included an issue of one day's food rations. At the end of the day they stayed for the night at a government hostel and then received rations for the next day. The amount and quality of the food differed according to rank, with administrators eating better than dispatch riders.

With the rise of cities and towns there is an increase in importance of the commercial hospitality sector. History of the Peloponnesian War, in which the events from $431 \mathrm{BC}$ to $411 \mathrm{BC}$ are related, is a text marking a significant departure from the literary style of historical writing. Thucydides wrote a military history, he is held to be scrupulous in his presentation of the facts as he abstains from commentary on social conditions, chronicles the events by seasons, and does not discuss state policy unless it refers to the progress of the war. Crucially, he interprets mankind's nature and behaviour as a result of man's own actions rather than claiming that man's destiny is controlled by the Gods or other fates outside his influence. In the text is the word 
katagogion, which is taken to mean inn or hostelry. From the context this can be understood in the commercial sense, and is one of the oldest references to largescale hospitality.

\begin{abstract}
"The city the Thebans gave for about a year to some political emigrants from Megara, and to the surviving Plataeans of their own party to inhabit, and afterwards razed it to the ground to its very foundations, and built on to the precinct of Hera an inn two hundred feet square, with rooms all round above and below" (Thucydides, The Peloponnesian War, 3:68)
\end{abstract}

The same word, katagogion, appears in the writings of Xenophon, in this case they are to be constructed by the city-state for the ship owners, merchants and visitors; these inns bestow various benefits to the growing and developing city:

\begin{abstract}
"When [city] funds were sufficient, it would be a fine plan to build more inns for ship owners near the harbours, and convenient places of exchange for merchants, also inns to accommodate visitors. Again, if inns and shops were put up both at Peiraieus [the port severing Athens] and in the city [Athens] for retail traders, they would be an ornament to the state and at the same time the source of considerable revenue" (Xenophon, Ways and Means, 3:12-13)
\end{abstract}

This was just one of a series of economic measures, proposed by Xenophon, that focused on attracting more foreign residents to Athens, both to strengthen and stabilise the Athenian economy and raise public funds.

Inns were clearly of different standards, some by no means unpleasant. One author whilst reflecting on a person's journey through life uses inns, comfortable and pleasing ones, as metaphor for a distraction to personal development.

"What then is usually done? A Man who acts as a traveller would do on his way to his own country, when he enters a good inn, and being pleased with it should remain there. Man, you have forgotten your purpose: you were not travelling to this inn, but you were passing through it. But this is a pleasant inn. And how many other inns are pleasant? And how many meadows are pleasant? Yet these are only for passing through. But your purpose is this, to return to your country, to relieve your kinsmen of anxiety, to discharge the duties of a citizen, to marry, to beget children, to fill the usual magistracies" (Arrian's Discourses of Epictetus 2.23) 
The literature also shows that by $400 \mathrm{BC}$ commercial hospitality was necessary to bring tourists or traders to the city and a key source of revenue. Commercial hospitality was a distinct and separate sector and it includes large-scale provision of food, beverage and accommodation. Commercial hospitality existed for those who did not have a network of private hospitality or receive hospitality by the state. As well as attracting traders, the commercial sector was seen as a means of economic stimulus and an integral means of enhancing the influence of the state beyond its borders.

\section{Roman Pompeii - The Importance of Historical Sites.}

A great deal of information and insight can be gained from the analysis of the literature and individual artefacts, however archaeological investigation can provide a great deal more in terms of reinforcement and enhancement of understanding. As O'Gorman, Baxter, and Scott (2007) noted, there are many sites associated with commercial hospitality in classical Rome but amongst these, one of the most significant is Pompeii. The almost instantaneous destruction and preservation of the city by the eruption of Mount Vesuvius on the 24th August 79 AD, and its literal fossilisation as an archaeological site created the unique sites of Pompeii and Herculaneum in Italy near modern day Naples. The comparative analysis states in the official World Heritage Site designation documentation prepared by UNESCO, "nowhere else is it possible to identify any archaeological site that even remotely stands comparison with these two classical towns" (UNESCO, 1996, p. 52). At the time of its destruction the city of Pompeii had a population of approximately 10,000 people. Pompeii was lost for 1,600 years before its accidental rediscovery in 1748 , since then systematic excavation and analysis took place on a huge scale, hindered very little by the usual taphonomic (decay and degration) processes which traditionally affect the preservation of archaeological remains (Renfrew \& Bahn, 1991).

O'Gorman et al (2007) note that the excavation of Pompeii has provided an extraordinarily detailed insight into the commercial hospitality industry of a city at the height of the Roman Empire. Pompeii is of importance to the examination of the Roman commercial hospitality industry as it was a major centre of commerce and entertainment in the Roman world, and commercial hospitality existed in a highly organised fashion. Garnsey (1999) notes that typically the houses in Pompeii did not have the basic utilities required to permit safe domestic preparation and consumption of food. Consequently there was a significant requirement on commercial hospitality provision that fuelled subsequent development, growth and entrepreneurial activity in the sector. Wallace-Hadrill (1994) however notes that the material remains of commercial hospitality establishments in Pompeii makes exact identification difficult. Not least, because no two inns or taverns are exactly alike; the problem of certain identification is also compounded by the fact that many 
establishments' second floors are missing. Packer (1978) notes that these missing second floors could have had apartments for rent, storage space, guest space or rooms for innkeepers and their families and staff. What would seem to be important is that there were two basic types of establishment, one that deals with accommodation and the other with food and drink. Using a wide variety of data sources O'Gorman (2007b) created a summarised table of the various hospitality businesses (figure 1).

[Place here Figure 1: Commercial Hospitality Establishments in Ancient Rome]

Hospitiae were establishments that offered rooms for rent, and often food and drink to overnight guests; some hospitiae were expressly fabricated for business purposes, although a number of them represent secondary uses of existing private homes in Pompeii. Stabulae were hospitiae with facilities to shelter animals; often found just outside the city, close to the city gates, the often described as the ancient equivalent of modern motels or, more romantically, coaching inns; they had an open courtyard surrounded by a kitchen, a latrine, and bedrooms with stables at the rear. Businesses within city gates were smaller than those in the countryside, due to pressure of space. Cauponae were establishments that provided meals, drink, and maybe lodgings; Popinae were limited to serving food and drink. Some may have offered sit down meals; this term was often used to describe public eating-houses. Hospitiae, stabulae, tabernae, and popinae should not always be understood as standalone businesses; often a hospitia or stabula would have a taberna or popina connected to it.

Ellis (2004) argues that Pompeii has approximately 160 properties that could have been bars and restaurants, as well as numerous hotels. These have been found together with detailed kitchens and bakeries some with fossilised loaves of bread. O'Gorman (2007b) highlights a cluster of hospitality establishments in the centre of Pompeii (Figure 2); less than two blocks from the busiest street and close to the administrative centre. Along with other building Figure 2 shows the floor plan of the largest hospitium identified so far in Pompeii and it could accommodate more than fifty guests and also had a large secluded garden. The main entrance is flanked by two bedrooms on either side with door opening into the atrium; left of the atrium is a kitchen, another bedroom, and a staircase to the upper floor. Along the back wall of the atrium, there are three rooms; the latrine and a dining room are to the right of the walkway. Off the walkway to the left, are two rooms, one of which probably was a storeroom. On the east side was another entrance from the street; an entrance from the garden led to a large area, with a room connected to it, which opened onto a large kitchen garden; possibly customers dined here in the garden with three alcoves on the north side providing shelter. It was in the atrium of this building that a graffito with the word 'Christianos' was found (CIL IV 679) 
[Figure 2]

Adjacent but not internally connected to the hospitium is a restaurant with a main dining room and a connecting smaller room with a latrine in back. One of the inscriptions in front attests to the fine wine served here (CIL IV 815). The name of the restaurateur was Drusus (CIL IV 814) who posted a sign in front of his bar which forbade loitering (CIL IV 813); the sign may have been there because the restaurant was close to Grand Lupanar. Grand Lupanar has 10 rooms, five on each floor; from the layout it appears that only the first floor was devoted to sex for profit. Within each room on the first floor is the typical masonry bed used for sexual encounters, but not for sleep; there is even a concrete 'pillow' at the head of the bed. On the interior walls is the greatest cluster of hic bene futui graffiti in the city and above the door into each room is an erotic picture depicting a couple in the various positions of the sex act or foreplay. In each case the setting of the picture is in more comfortable surroundings than the cramped room behind it! The bar shown at 8 is a typical tavern; similar to another bar Figure 3. Here a long counter took up most of Room 1, this was for selling food and drink to passing customers; Room 2 contained stools for customers to sit on.

[Figure 3]

O'Gorman (2007a) details that accommodation along major roads and at city gates gained a reputation for attracting lower classes who were too poor or socially insignificant to have developed a network of personal hospitality. Commercial hospitality businesses existed for travellers, merchants, and sailors who came to trade and sell, or those who were stopping overnight along the way to other destinations. Individual places of hospitality either offer associated services, or are located near other places of hospitality provision. Although originally at lower levels, the subsequent provision of higher levels of hospitality establishment and service was a direct consequence of the ability of the higher classes to afford to travel to lands where they were not known, but it enables them to be in environments which are commensurate with their wealth and status, without the need to establish a household there.

Commercial motives are evident in both the organisation of facilities and advertising efforts, menus of the day etc. Early entertainments and events were highly organised activities, central to the leisure of the day and given prime geographical location to emphasise this importance. The skills involved in organising these mass 
spectacles are not to be overlooked. Pompeii in its role as a centre of leisure would have attracted and required the best hospitality employees that the Empire could offer, in order to maintain and improve its reputation. It was ultimately a place for mercantile and leisure activities with a correspondingly well developed and sophisticated commercial hospitality provision.

\section{Caravanserais - Traditional hospitality brings commerce and trade}

From at least the seventh Century AD there is a strong Middle Eastern literary tradition based around hospitality, particularly that of the Bedawin. The collection of poems gathered together in the ninth century AD, known as the Hamāsa al-sughrā, make frequent references to hospitality (Hamāsa, 1970). The poets observe that at night the fires attract travellers, without inquiring about the stranger, or even when the stranger is known to be an enemy, a meal is prepared for the guest; then he is given a place to sleep; sometimes they sleep with the family, at other times a special tent is erected. Even if they are a timid and gentle household, they will endure any hardship or inconvenience and are always ferocious in defence of their guests. Hospitality is frequently mentioned in Islamic traditions known as hadiths, one such tradition notes that if the guest stays longer than the 'three days' it becomes charity, and it is forbidden for a guest to stay when he becomes a burden to his host (ibn Anas, 1999).

Caravanserais were hostels for travellers, where accommodation was often given for free for the traditional three days, although in reality most travellers would continue with their journey after just the one night. In contrast to the mediaeval western monasteries, caravanserais could also be used as commercial centres for merchants. Establishing caravanserais to provide hospitality for travellers is often reflected among the traditions and writings, for example the historian al-Tabari (c 910 AD) records how the governor of Samarqand (now called Samarkand, Uzbekistan) in 719 AD was ordered to:

"establish inns in your lands so that whenever a Muslim passes by, you will put him up for a day, and a night and take care of his animals; if he is sick, provide him with hospitality for two days and two nights; and if he has used up all of his provisions and is unable to continue, supply him with whatever he needs to reach his hometown." (al-Tabarī, 1989)

Samarqand was located along the Silk Routes, one of the most important trading routes in the region, and no doubt had a regular supply of traders and travellers. This ancient route is one of the best known of the world's historical trading routes, traditionally running from Xian in northern China through Iran and on to Istanbul. There are other evidences from the seventh and eighth centuries: ibn Abd al-Hakam 
(ibn Abd al-Hakam, 1922), who died in 860 AD, described caravanserais built by the governor of Egypt; and there is evidence from 710AD when the ruler of Damascus was roundly criticised for funding the construction of a Mosque rather than maintaining the roads and building caravanserais (al-Muqaddasī, 1877). In the ninth and tenth centuries there was a well established record of hospitable works for travellers in Bukhara, Uzbekistan (al-Narshakhī, 1954) and in the eleventh century a governor in Western Iran had "built in his territories three thousand mosques and caravanserais for strangers" (ibn Abd al-Hakam, 1922, p. 113). Provided for sound theological reasons, the building of caravanserais would make the ruler renowned for ever; and gather the benefits in eternal life (al-Mulk, 1994).

A comprehensive system of caravanserais existed all across Iran and throughout the whole Islamic world, providing hospitality and care for travellers both pilgrims (Petersen, 1994) and merchants (Yavuz, 1997). In Iran today 120 of these caravanserais still exist in various states of repair. Some have been redeveloped and are used as city centre hotels, others still operate like the caravanserais of old, unfortunately a great number suffer from inappropriate restoration and are now in an advanced state of decay and disrepair. One example is at Dayr-i Gachin, two hours south of Tehran, after a detailed archaeological and historical survey, Shokoohy (1983) argues that this caravanserai dates back to the $3^{\text {rd }}$ Century A.D. It was originally established by the Sasanian Emperor Ardashir I (A.D. 224-41), throughout the last millennium and a half it has had many uses including a Zoroastrian sanctuary, however it had always provided accommodation for travellers. It was abandoned in the late $19^{\text {th }}$ Century when the alignment of the road was significantly altered. From the plan [Figure 4] the full extent of the caravanserai can be seen including stratified accommodation, bathhouse and a mosque.

[Insert Figure 4 here]

\section{Discussion and Conclusions}

This paper has redressed some of the fanciful and often absurd rhetoric that has permeated some previous discussions into the origins and evolution of the commercial hospitality industry. What was lacking from the declarative and judgemental approaches identified at the very beginning of this paper was a clear understanding of contexts of hospitality. Also analysing data from a different period of history or culture, then looking for examples of similar practices in traditional cultures in Bedouin or nomadic cultures today, whilst illuminating, can have its difficulties. The organic and spiritual qualities that subsist within the domestic context, and indeed shown by individuals offering hospitality in the commercial context, have not been replaced; the contexts are simply different. 
From the empirical research summarised, it is clear that hostels and inns in Mesopotamia date back to at least 2000 B.C. and they were controlled by the laws of the time. Also, within Classical Rome, towns like Pompeii had a flourishing diversified and stratified commercial hospitality industry. There was a wide range of facilities on offer providing a diverse range of services, from the large central hotels located in the middle of a town and other complimentary facilities to the caravanserais along the main trade routes. Commercial hospitality has always been seen as a source of revenue for the state, for individuals and, indeed, businesses. Outstanding establishments within the commercial hospitality context have always been considered as an enhancement to the standing of the city and provided a source of revenue. Similarly, hospitality professionals commanded high status within society, frequently established through professional practice and writings. Crossing thresholds of commercial hospitality also guaranteed and provided physical protection, sanctuary and security.

In examining the context of the commercial hospitality relationship it is evident that the sector was already distinct and separate from domestic and civic hospitality. There was a large-scale provision of food, beverage and accommodation: the sector supported and attracted travellers; was necessary and integral for business; and served the needs of merchants. A Stratified and diversified commercial hospitality industry existed and hospitality establishments became clustered within cities. In other words, the supply of commercial hospitality was already subject to the demand of market forces focused on urban centres to which the merchants were attracted. Commercial hospitality existed for those who did not have an extensive network of private hospitality or were either insufficiently privileged to receive the hospitality of the state or in such an impoverished personal situation that they required it. The commercial provision was not homogeneous, and stratified levels of provision offered different levels of service. Indeed, commercial hospitality had always to be paid for and more money bought a better provision and quality of service. Establishments quickly gained reputations through the quality of their staff and standard of service provided, and equally through the character and behaviour of their clientele. Finally, one constant and unremitting aspect of the commercial industry and those employed within it was the increasing legal control they were subject to.

This paper has highlighted an important but overlooked area of hospitality management research: the historical roots and evolution of the commercial industry. There is a clear need for other studies that explore different but contemporaneous civilisations. For example, an exploration of Ancient Chinese commercial hospitality practices and the emergent industry along the Silk Routes could be particularly enlightening as it would provide a useful comparison to the hospitality practices of early Europe. Another option would be to develop the research vertically into other periods of time within the same geographical region. A further direction for research would be to progress into the next period of European history (the Mediaeval Period) as it would be fascinating to see how the commercial industry continued to adapt and change under different economic circumstances. Further research could also 
explore in greater detail the linkage, highlighted by Xenophon, between the emergence of commercial hospitality with the emergence of commercial trade; then in turn the links to economic production levels capable of producing surpluses. This would then provide a more systemic explanation which could show if commercial hospitality develops out of a general increase in commercial activity or is a driving force behind it.

This paper has clearly shown that the commercial hospitality industry (provision of food, beverage and often accommodation within business) has not appeared outof-the-blue, it has existed for at least 4000 years. Hospitality management research should focus on deepening understanding of management practice within the industry, separate from domestic hospitality practices; that is best left to anthropologists and sociologists who have the necessary training and research skills. When engaging in historical research, too often hospitality academics have resorted to secondary or tertiary sources and lacked the language ability to read and translate the original texts that are required. As hospitality academics, researchers, students and practitioners we should be immensely proud of the rich and incredibly diverse heritage our industry has. There is nothing wrong with providing a commercial hospitality service within particular institutional forms (now called the hospitality industry, but known by an assortment of different names in the past). Hospitality research should focus on deepening understanding of the industry; learning from the past will help to inform the future. 


\section{References}

al-Mulk, N. (1994). Siyāsatnāmah. Tehran: Shirkat-i Intisharat-i llm va Farangi.

al-Muqaddasī, M. A. (1877). Kïtāb absan al-taqāsīm fi ma'rifat al-aqālimm. Brill: Lugduni Batavorum.

al-Narshakhī, M. (1954). The History of Bukhara by Muhammad Narshakhī; translated from a Persian abridgement of the Arabic original by Narshakhi. Cambridge: Mediaeval Academy of America.

al-Tabarī (1989). Ta'rikh al-rusul wa al-mulūk. Albany: State University of New York Press.

Bardi, J. A. (2007). Hotel Front Office Management. Hoboken: John Wiley \& Sons.

Ellis, S. J. R. (2004). The Distribution of Bars at Pompeii: Archaeological, spatial and viewshed analyses. Journal of Roman Archaeology, 17, 371-384.

Finley, M. I. (1983). Ancient Slavery and Modern Ideology. Harmondsworth: Clarendon Press.

Garnsey, P. (1999). Food and Society in Classical Antiquity. Cambridge: Cambridge University Press.

Gillespie, C., \& Morrison, A. (2001). Elite Hotels: Painting a Self-Portrait. International Journal of Tourism Research, 3(2), 115-121.

Hamāsa (1970). Kitāb al-wahshīyāt: wa-huwa al-Hamāsa al-sughrā li-Abī Tammām Habỉ ibn Aws al-Tāit; 'allaqa 'alayhi wa-haqqaqahn 'Abd al-'Azīz alMaymanī al-Rājkūtīi wa-zāda fī hawāshīhi Mahmūd Muhammad Shākir. alQāhirah Dar al-Ma'ārif bi-Misr.

ibn Abd al-Hakam, A. (1922). Kitāb Futūh Misr wa-ahb ārihā. New Haven: Yale University Press.

ibn Anas, M. (1999). al-Muwatta' lil-Imām Mālik ibn Anas. al-Qāhirah: Dār al-Hadīth.

Jones, T. B., \& Snyder, J. W. (1961). Sumerian Economic Texts from the Third Ur Dynasty. A catalogue and discussion of documents from various collections. Minneapolis: University of Minnesota Press.

King, C. (1995). What is hospitality? International Journal of Hospitality Management, $14(3 / 4), 219-234$.

Lattin, G. W. (1989). The Lodging and Food Service Industy. East Lansing: Educational Institute of the American Hotel \& Motel Association.

Medlik, S., \& Ingram, G. (2000). The Business of Hotels. Oxford: Butterworth Heinemann.

Morrison, A. (2001). Entrepreneurs transcend time: a biographic analysis. Management Decision, 39(9), 784-790.

Muhlmann, W. E. (1932). Hospitality. In E. R. A. Seligman (Ed.), Encyclopaedia of the Social Sciences. New York: Macmillan.

O'Gorman, K. D. (2007a). Dimensions of Hospitality: Exploring Ancient and Classical Origins. In C. Lashley, A. J. Morrison \& P. Lynch (Eds.), Hospitality: A Social Lens. Advances in Tourism Research (pp. 17-32). Oxford: Elsevier.

O'Gorman, K. D. (2007b). Discovering Commercial Hospitality in Ancient Rome. The Hospitality Review, 9(2), 44-52.

O'Gorman, K. D., Baxter, I., \& Scott, B. (2007). Exploring Pompeii: Discovering hospitality through research synergy. Tourism and Hospitality Research, 7(2), 89-99.

O'Connor, D. (2005). Towards a new interpretation of 'hospitality'. International Journal of Contemporary Hospitality Management, 17(3), 267-271.

Packer, J. E. (1978). Inns at Pompeii: A Short Survey. Cronache Pompeiane. Rivista dell'Associazione Internazionale 'Amici di Pompei', 4, 5-53. 
Petersen, A. (1994). The Archaeology of the Syrian and Iraqi Hajj Routes. World Archaeology, 26, 47-56.

Pritchard, J. B. (1955). The Ancient Near East in pictures relating to the Old Testament. Princeton: Princeton University Press.

Renfrew, C., \& Bahn, P. (1991). Archaeology: Theories, Method \& Practice. London: Thames \& Hudson.

Richardson, M. E. J. (2000). Hammurabi's Laws: Text, translation and glossary. Sheffield: Sheffield Academic Press.

Rutes, W., \& Penner, R. (1985). Hotel Planning and Design. New York: Watson-Guptill.

Shokoohy, M. (1983). The Sasanian Caravanserai of Dayr-i gachin, South of Ray, Iran. Bulletin of the School of Oriental and African Studies, University of London, 46(3), 445-461.

UNESCO (1996). World Heritage List Extract: Pompei and Ercolano, Italy. Paris: UNESCO World Heritage Centre.

Wallace - Hadrill, A. (1994). Houses and Society in Pompeii and Herculaneum. Princeton: Princeton University Press.

Wood, R. (1994). Some theoretical perspectives on hospitality. In A. Seaton, C. Jenkins, R. Wood, P. Dieke, M. Bennet, L. MacLellan \& R. Smith (Eds.), Tourism: The State of the Art (pp. 737-742). Chichester: John Wiley \& Sons Ltd.

Yavuz, A. T. (1997). The Concepts That Shape Anatolian Seljuq Caravanserais. Muqarnas, 14, 80-95. 
Figure 1: Commercial Hospitality Establishments in Ancient Rome

\begin{tabular}{|l|l|l|}
\hline Latin Name & Description and facilities & $\begin{array}{l}\text { Modern } \\
\text { Equivalent }\end{array}$ \\
\hline Hospitium & $\begin{array}{l}\text { Larger establishments that offered rooms for rent, and } \\
\text { often food and drink to overnight guests; often } \\
\text { specifically built for business purposes. }\end{array}$ & Hotel \\
\hline Stabula & $\begin{array}{l}\text { Buildings with open courtyard surrounded by a kitchen, } \\
\text { a latrine, and bedrooms with stables at the rear. Often } \\
\text { found just outside the city, close to the city gates; } \\
\text { offered food, drink and accommodation. }\end{array}$ & $\begin{array}{l}\text { Coaching } \\
\text { Inn }\end{array}$ \\
\hline $\begin{array}{l}\text { Taberna } \\
\text { Ganeap }\end{array}$ & $\begin{array}{l}\text { Sold a variety of simple foods and drink. They usually } \\
\text { contained a simple L-shaped marble counter, about six } \\
\text { to eight feet long }\end{array}$ & Bar \\
\hline $\begin{array}{l}\text { Popina } \\
\text { Caupona }\end{array}$ & $\begin{array}{l}\text { Served food and drink, offered sit down meals; this term } \\
\text { was often used to describe public eating-houses and } \\
\text { sometimes included a few rooms. }\end{array}$ & Restaurant \\
\hline Lumpanar & \begin{tabular}{l} 
Provided a full range of services of a personal nature. \\
\hline
\end{tabular} & Brothel \\
\hline
\end{tabular}


Figure 2: Cluster of commercial hospitality establishments in the centre of Pompeii

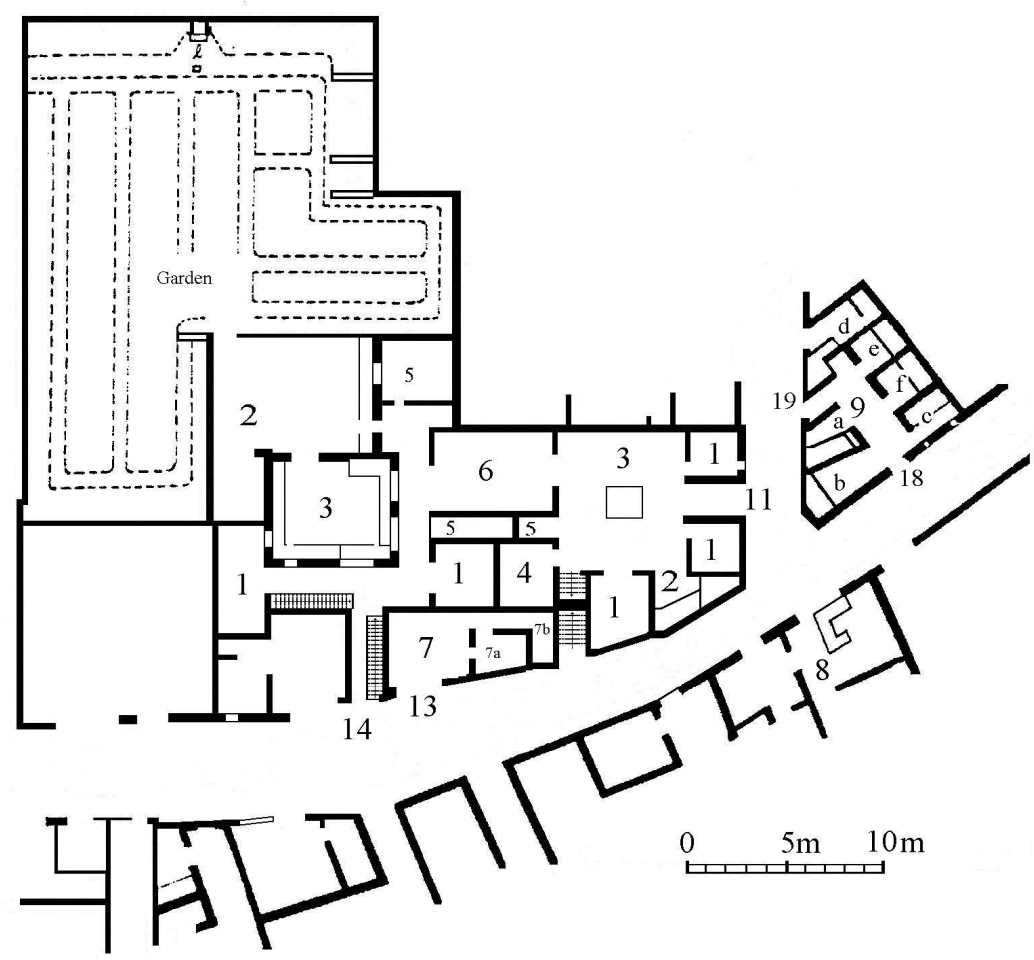

$$
\begin{array}{ll}
\text { Hotel } & \text { (VIl.xi.11/14) } \\
& 1 \text { Bedroom } \\
& 2 \text { Kitchen } \\
& 3 \text { Atrium } \\
& 4 \text { Triclinium } \\
5 \text { Store } & \text { Tablinum }
\end{array}
$$

Popina (VII.xi.13)

7 Serving Room

7a Store

7b Latrine

Other establishments

8 Taberna

9 Grand Lupanar (VII.xii.18-19) 
Figure 3:

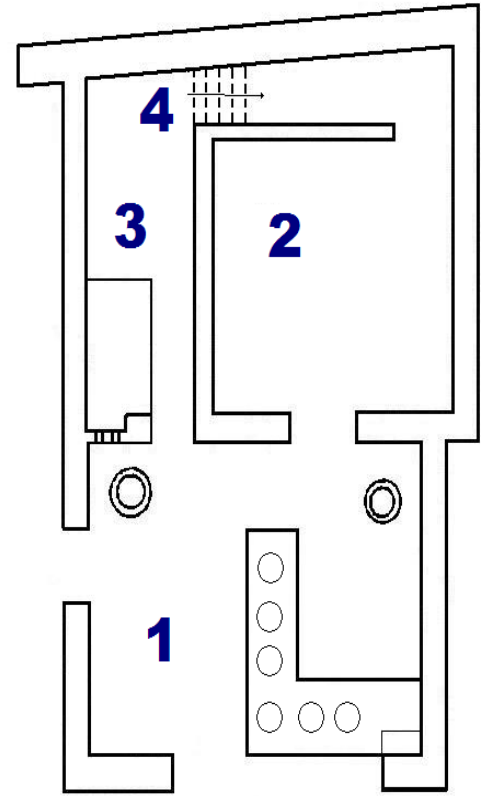

Level 1 (Shown)

1. Main selling area

2. Serving area

3. Kitchen

4. Stairs

Level 2 (Destroyed)

Would have contained the Restaurateur's accommodation 
Figure 4: Caravanserai at Dayr-I Gachin, Iran

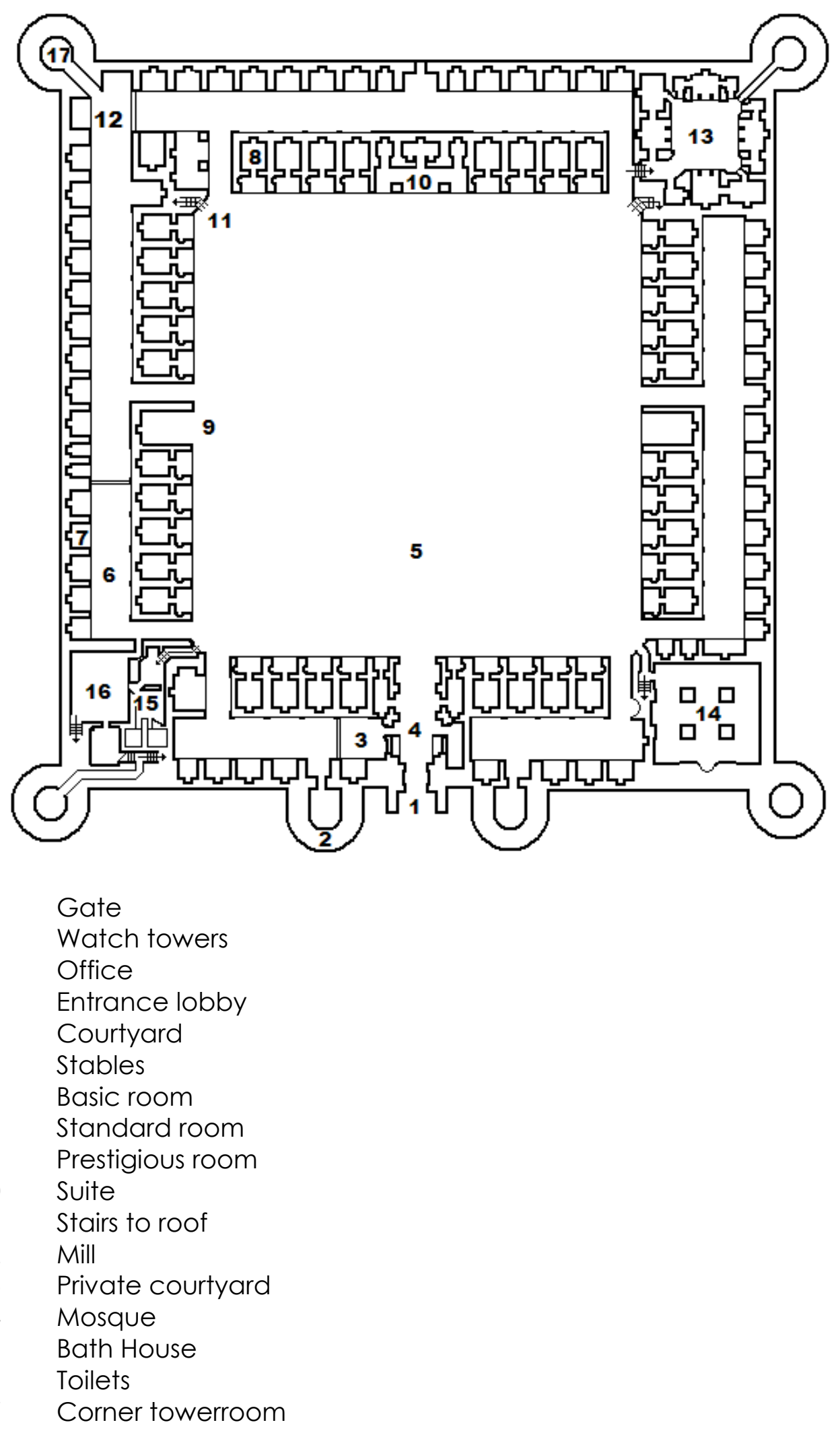

